\title{
Variation and taxonomic value of some mandibular characters in red-toothed shrews of the genus Sorex L. (Insectivora: Soricidae)
}

\author{
Mikhail V. Zaitsev \& Barbara Rzebik-Kowalska
}

\begin{abstract}
The variability of five mandibular characters of the long-tailed shrews of the genus Sorex (the position of mental foramen, the structure of mandibular/postmandibular foramina complex, the structure of condyloid process, the pattern of pigmentation of the first lower incisor i1, and the color of tooth pigment) was examined. It is shown that each of these features is characterized by a specific level of variation. It should take into account in identifying and in the formulation of taxonomic hypotheses. On the basis of the obtained data the assumption of a specific taxonomic position of $S$. trowbridgii and $S$. mirabilis in relation to the traditionally recognized subgenera Sorex and Otisorex was made.
\end{abstract}

KEY WORDS: Sorex, taxonomy, morphology, paleontology.

Mikhail V. Zaitsev [mikzaitsev@yahoo.com] Zoological Institute, Russian Academy of Sciences, Universitetskaya nab., 1, Saint-Petersburg 199034, Russia; Barbara Rzebik-Kowalska [rzebik@isez.pan.krakow.pl] Institute of Systematics and Evolution of Animals, Polish Academy of Sciences, Slawkowska 17, 31-016 Kraków, Poland.

\section{Изменчивость и таксономическая ценность некоторых признаков нижнечелюстной кости землероек-бурозубок рода Sorex L. (Insectivora: Soricidae)}

\author{
М.В. Зайцев, Б. Ржебик-Ковальска
}

\begin{abstract}
РЕЗЮМЕ. Изучена вариабельность пяти признаков нижней челюсти у землероек-бурозубок рода Sorex L. (положения подбородочного отверстия, структуры комплекса нижнечелюстных отверстий, формы межсуставной поверхности сочленовоного отростка, характера пигментации нижнего края переднего резца, общего тона окраски зубов). Показано, что каждый из этих признаков характеризуется специфическим уровнем изменчивости, который необходимо учитывать в практической работе при диагностике и выдвижении таксономических гипотез. На основании полученных данных высказано предположение о возможном специфическом статусе S. trowbridgii и S. mirabilis по отношению к традиционно выделяемым в составе рода подродам Sorex и Otisorex.
\end{abstract}

КЛЮЧЕВЫЕ СЛОВА: Sorex L., таксономия, морфология, палеонтология.

\section{Introduction}

The genus Sorex Linnaeus, 1758 contains 74 species of red-toothed shrews distributed mainly in the boreal region of the Holarctic (Lapini \& Testone, 1998; Wolsan \& Hutterer, 1998; Brünner et al., 2002). The Palearctic and Nearctic parts of its range differ significantly in their species composition. The species of the subgenus Sorex Linnaeus, 1758 are mainly distributed in the Old World. The species of the subgenus Otisorex De Kay, 1942, as a rule, occupy the New World territories. The taxonomy of both subgenera is primarily based on the skull and upper tooth characters (Zyll de Jong, 1978; Junge \& Hoffmann, 1981; Dolgov, 1985; Yudin, 1989). The mandibular and lower tooth characters have been used rather seldom in their taxonomy (Sergeev \& Kharitonova, 1987; Carraway, 1995). On the other hand, the tooth characters play an important role in the fossil species discrimination(Repenning, 1967; Reumer, 1984, 1985; Rzebik-Kowalska, 1991, 2000; Storch, 1995; Qiu
\& Storch, 2000; Zaitsev \& Baryshnikov, 2002). As a result, the taxonomy of the recent and fossil species was created to a high degree independently, because different sets of characters were used for their diagnoses and taxonomic conclusions. Besides, the importance of common characters in the diagnostics and taxonomic conclusions is sometimes differently understood. The variation of particular diagnostic characters has not been adequately studied and only a few papers touching this question can be cited (e.g. Dannelid, 1989).

In the present paper, the prime subject of investigations is the variation study of the five mandible characters usually used in the paleontological and sometimes in the neontological research of the red-toothed shrews. They are: the position of the mental foramen, the structure of the mandibular/postmandibular foramina complex, the structure of the condyloid process, the pattern of pigmentation in the first lower incisor il and the color of the tooth pigment. 
Figure 1. Position of the mental foramen in Sorex species. A - morphotype 1; B - morphotype 2 .

\section{Materials and methods}

21 recent and four fossil species of shrews were studied. Most of them belong to the Palearctic group of the subgenus Sorex with the exception of one American species of this subgenus, S. trowbridgii Baird, 1857, which was also examined. Three Palearctic (S. camtschaticus Yudin, 1972, S. leucogaster Kuroda, 1933, and S. portenkoi Stroganov, 1956) and one Nearctic (S. vagrans Baird, 1857) representatives of the subgenus Otisorex were also analyzed. For each species a random sample of specimens from different localities was prepared (Appendix). The subadult specimens were preferred. The sex was not distinguished.

Three European fossil species ( $S$. praearaneus Kormos, 1934, S. runtonensis Hinton 1911, and S. thaleri
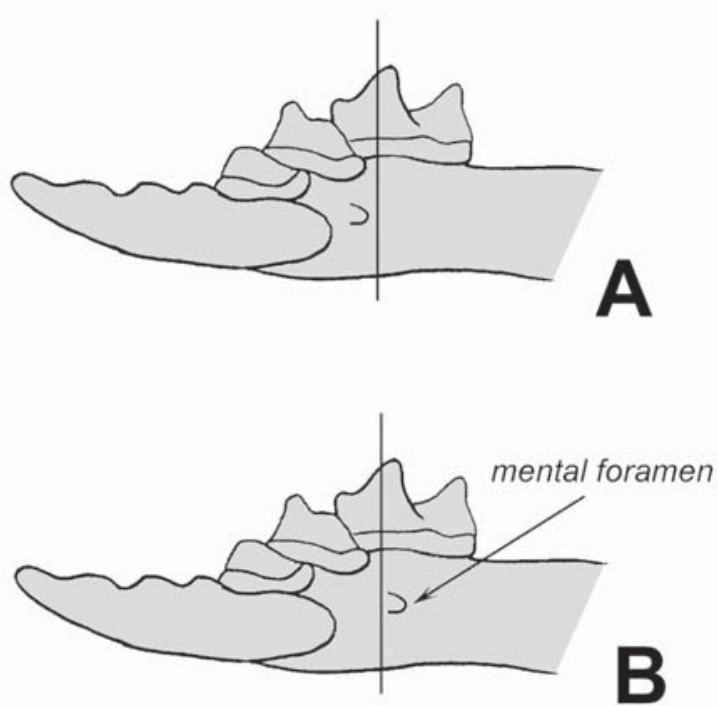

Table 1. Variability of three structural features of the mandible (in \%; frequencies more $90 \%$ are highlighted).

\begin{tabular}{|c|c|c|c|c|c|c|c|c|}
\hline \multirow{3}{*}{ Species } & \multicolumn{2}{|c|}{ Mental foramen } & \multicolumn{3}{|c|}{ MPF complex } & \multicolumn{3}{|c|}{ Interarticulation area } \\
\hline & \multicolumn{2}{|c|}{ Morphotypes } & \multicolumn{3}{|c|}{ Morphotypes } & \multicolumn{3}{|c|}{ Morphotypes } \\
\hline & 1 & 2 & 1 & 2 & 3 & 1 & Intermediate & 2 \\
\hline S. araneus & 0.0 & 100.0 & 8.0 & 92.0 & 0.0 & 16.0 & 60.0 & 24.0 \\
\hline S. asper & 0.0 & 100.0 & 0.0 & 100.0 & 0.0 & 62.5 & 25.0 & 12.5 \\
\hline S. satunini & 0.0 & 100.0 & 5.4 & 81.1 & 13.5 & 17.1 & 20.0 & 62.9 \\
\hline S. tundrensis & 0.0 & 100.0 & 0.0 & 100.0 & 0.0 & 58.0 & 16.0 & 26.0 \\
\hline S. caecutiens & 0.0 & 100.0 & 2.0 & 96.0 & 2.0 & 96.0 & 4.0 & 0.0 \\
\hline S. isodon & 0.0 & 92.0 & 12.0 & 86.0 & 2.0 & 100.0 & 0.0 & 0.0 \\
\hline S. unguiculatus & 0.0 & 100.0 & 0.0 & 100.0 & 0.0 & 89.6 & 10.4 & 0.0 \\
\hline S. roboratus & 0.0 & 100.0 & 6.0 & 76.0 & 18.0 & 46.7 & 46.7 & 6.6 \\
\hline S. gracillimus & 34.3 & 65.7 & 0.0 & 81.4 & 18.6 & 94.2 & 2.9 & 2.9 \\
\hline S. minutus & 40.0 & 60.0 & 0.0 & 92.5 & 7.5 & 82.4 & 12.3 & 5.3 \\
\hline S. volnuchini & 0.0 & 100.0 & 0.0 & 67.6 & 32.4 & 81.1 & 8.1 & 10.8 \\
\hline S. daphaenodon & 0.0 & 100.0 & 2.0 & 98.0 & 0.0 & 22.4 & 23.5 & 54.1 \\
\hline S. raddei & 31.8 & 68.20 & 0.0 & 98.3 & 1.7 & 89.5 & 10.5 & 0.0 \\
\hline S. alpinus & 96.3 & 3.7 & 0.0 & 100.0 & 0.0 & 69.6 & 30.4 & 0.0 \\
\hline S. minutissimus & 0.0 & 100.0 & 0.0 & 72.6 & 27.4 & 39.6 & 33.7 & 26.7 \\
\hline S. mirabilis & 0.0 & 100.0 & 36.2 & 61.7 & 2.1 & 100.0 & 0.0 & 0.0 \\
\hline S. trowbridgii & 0.0 & 100.0 & 9.6 & 49.3 & 41.1 & 88.0 & 12.0 & 0.0 \\
\hline S. portenkoi & 0.0 & 100.0 & 98.3 & 1.7 & 0.0 & 90.4 & 9.6 & 0.0 \\
\hline S. leucogaster & 0.0 & 100.0 & 100.0 & 0.0 & 0.0 & 100.0 & 0.0 & 0.0 \\
\hline S. camtschaticus & 0.0 & 100.0 & 100.0 & 0.0 & 0.0 & 96.9 & 3.1 & 0.0 \\
\hline S. vagrans & 0.0 & 100.0 & 96.1 & 3.9 & 0.0 & 100.0 & 0.0 & 0.0 \\
\hline$\dagger$ S. paearaneus & 7.7 & 92.3 & 8.3 & 85.7 & 7.0 & 55.0 & 20.0 & 25.0 \\
\hline$\dagger S$. runtonensis & 0.0 & 100.0 & 3.8 & 93.3 & 2.9 & 18.0 & 62.0 & 21.0 \\
\hline$\dagger S$. thaleri & 0.0 & 100.0 & 40.6 & 46.3 & 3.1 & 6.3 & 28.2 & 65.5 \\
\hline$\dagger S$ doronichevi & 17.8 & 82.2 & 3.6 & 90.9 & 5.5 & 2.2 & 15.5 & 82.3 \\
\hline
\end{tabular}


Jammot, 1989) were excavated in Polish Pliocene and Pleistocene localities: Zamkowa Dolna Cave A, Kielniki3B(Late Pliocene), Kadzielnia (Pliocene/Pleistocene boundary), Kielniki 3A, Kamyk (Early Pleistocene), Kozi Grzbiet (Early/Middle Pleistocene) and Oblazowa Cave and Oblazowa Cave (site 2) (Late Pleistocene) (Rzebik-Kowalska, 1991, 1994, 2003). The single Caucasian fossil species, S. doronichevi Zaitsev et Baryshnikov, 2002, derives from layers 5 and 7 of the Treugolnaya Cave (Zaitsev \& Baryshnikov, 2002).

In the frequency analysis the left and right mandibles were counted separately. The degree of the variability of characters was measured by means of the Shannon entropy $(H)$ :

$$
H=-\Sigma p_{\mathrm{i}} \ln p_{\mathrm{i}}
$$

where $p i$ is a probability of the morphotype distribution of the character in particular species.

The entropy can range from 0 to 0.693 for the characters with two morphotypes, and from 0 to 1.099 for the characters with three morphotypes. The minimum value $(H=0)$ means the complete absence of the character variation, so it is observed in specimens characterized by only one morphotype. The maximum value $(H=0.693 ; 1.099)$ indicates the uniform distribution of morphotypes in the specimens examined.

The most interesting is the comparison of the obtained data with the median value of entropy. Thus, the value lesser than median can be considered as low variability of the character, and the value greater than median as high variability of character. The numerical median value for two and three morphotypes equals to 0.346 and 0.550 respectively.

\section{Results}

\section{Position of the mental foramen}

General variation and patterning. In the Soricinae species the mental foramen opens on the buccal side of the mandible and is usually situated under $\mathrm{p} 4$ or $\mathrm{m} 1$. The position of the mental foramen can be traced by the location of its posterior edge. Two morphotypes were recognized (Fig. 1.).

Morphotype 1. The mental foramen is in the anterior position. Its posterior edge is situated under $\mathrm{p} 4$, in front of or exactly under its posterior edge, or a little backward of this edge Fig. 1A).

Morphotype 2. The mental foramen is in the posterior position. Its posterior edge is situated more backward than in the morphotype 1 (Fig. 1B).

Variation in the Sorex species. The frequency of morphotypes of the mental foramen position is presented in Tab. 1. It shows that the recent species (17 from 21) are characterized by its posterior position (92-100\%). Moreover, in 16 of them this position is almost invariable. The first morphotype visibly prevails only in $S$. alpinus $(96.3 \%)$. The entropy of the mental foramen position of all these species is very low (0-0.279) and has considerably lower median value (Fig. 5A).

Three species of the subgenus Sorex, S. gracillimus Thomas, 1907,S. minutus Linnaeus, 1766, and $S$. raddei Satunin, 1895 show a higher level of variation of this character. Their ratio of morphotypes is approximately $1: 2$. The data of $H$ for these species are rather high $(0.625-0.673)$ and considerably exceed the median value (Tab. 3).

Table 2. Variability of the pigmentation of teeth (in \%; frequencies more $90 \%$ are highlighted).

\begin{tabular}{|c|c|c|c|c|c|c|c|c|c|}
\hline \multirow{3}{*}{ Species } & \multirow{2}{*}{\multicolumn{2}{|c|}{$\begin{array}{c}\text { Pigmentation of } \\
\text { lower incisor } \\
\text { Morphotypes }\end{array}$}} & \multirow{2}{*}{\multicolumn{2}{|c|}{$\begin{array}{c}\text { Color of teeth pigment } \\
\text { Morphotypes }\end{array}$}} & \multirow{3}{*}{ Species } & \multirow{2}{*}{\multicolumn{2}{|c|}{$\begin{array}{c}\text { Pigmentation of } \\
\text { lower incisor }\end{array}$}} & \multirow{2}{*}{\multicolumn{2}{|c|}{$\begin{array}{c}\text { Color of teeth pigment } \\
\text { Morphotypes }\end{array}$}} \\
\hline & & & & & & & & & \\
\hline & 1 & 2 & 1 & 2 & & 1 & 2 & 1 & 2 \\
\hline S. araneus & 100.0 & 0.0 & 5.5 & 94.5 & S. raddei & 98.3 & 1.7 & 3.4 & 96.6 \\
\hline S. asper & 100.0 & 0.0 & 0.0 & 100.0 & S. alpinus & 96.2 & 3.8 & 16.7 & 83.3 \\
\hline S. satunini & 100.0 & 0.0 & 0.0 & 100.0 & S. minutissimus & 100.0 & 0.0 & 1.2 & 98.8 \\
\hline S. tundrensis & 98.3 & 1.7 & 3.3 & 96.7 & S. mirabilis & 100.0 & 0.0 & 0.0 & 100.0 \\
\hline S. caecutiens & 100.0 & 0.0 & 10.0 & 90.0 & S. trowbridgii & 4.5 & 95.5 & 0.0 & 100.0 \\
\hline S. isodon & 100.0 & 0.0 & 0.0 & 100.0 & S. portenkoi & 3.4 & 96.6 & 0.0 & 100.0 \\
\hline S. unguiculatus & 100.0 & 0.0 & 0.0 & 100.0 & S. leucogaster & 0.0 & 100.0 & 6.2 & 93.8 \\
\hline S. roboratus & 96.3 & 3.7 & 3.7 & 96.3 & S. camtschaticus & 0.0 & 100.0 & 3.1 & 96.9 \\
\hline S. gracillimus & 98.3 & 1.7 & 0.0 & 100.0 & S. vagrans & 2.5 & 97.5 & 8.0 & 92.0 \\
\hline S. minutus & 100.0 & 0.0 & 3.8 & 96.2 & $\dagger$ S. paearaneus & $100.0 *$ & 0.0 & 33.3 & 66.7 \\
\hline S. volnuchini & 100.0 & 0.0 & 6.6 & 93.4 & $\dagger S$. runtonensis & 100.0 & 0.0 & 3.0 & 97.0 \\
\hline S. daphaenodon & 100.0 & 0.0 & 0.0 & 100.0 & $\dagger S$. thaleri & $100.0 *$ & 0.0 & 3.3 & 96.8 \\
\hline & & & & & $\dagger S$. doronichevi & $100.0 *$ & 0.0 & 2.2 & 97.8 \\
\hline
\end{tabular}

* Data obtained on the less then 10 specimens. 
Table 3. Values of entropy $(H)$ in Sorex species (values exceeds median entropy level are highlighted).

\begin{tabular}{|c|c|c|c|c|c|}
\hline & Mental foramen & MPF complex & Inter-articulation area & Pigmentation of I1 & Color of the teeth pigment \\
\hline S. araneus & 0.000 & 0.280 & 0.942 & 0.000 & 0.213 \\
\hline S. asper & 0.000 & 0.000 & 0.900 & 0.000 & 0.000 \\
\hline S. satunini & 0.000 & 0.598 & 0.916 & 0.000 & 0.000 \\
\hline S. tundrensis & 0.000 & 0.000 & 0.959 & 0.086 & 0.145 \\
\hline S. caecutiens & 0.000 & 0.196 & 0.169 & 0.000 & 0.325 \\
\hline S. isodon & 0.279 & 0.462 & 0.000 & 0.000 & 0.000 \\
\hline S. unguiculatus & 0.000 & 0.000 & 0.335 & 0.000 & 0.000 \\
\hline S. roboratus & 0.000 & 0.686 & 0.891 & 0.158 & 0.158 \\
\hline S. gracillimus & 0.643 & 0.481 & 0.262 & 0.086 & 0.000 \\
\hline S. minutus & 0.673 & 0.267 & 0.573 & 0.000 & 0.162 \\
\hline S. volnuchini & 0.000 & 0.631 & 0.614 & 0.000 & 0.243 \\
\hline S. daphaenodon & 0.000 & 0.099 & 1.008 & 0.000 & 0.000 \\
\hline S. raddei & 0.625 & 0.087 & 0.337 & 0.086 & 0.148 \\
\hline S. alpinus & 0.149 & 0.000 & 0.615 & 0.162 & 0.451 \\
\hline S. minutissimus & 0.000 & 0.588 & 1.086 & 0.000 & 0.065 \\
\hline S. mirabilis & 0.000 & 0.747 & 0.000 & 0.000 & 0.000 \\
\hline S. trowbridgii & 0.000 & 0.939 & 0.368 & 0.184 & 0.000 \\
\hline S. portenkoi & 0.000 & 0.087 & 0.317 & 0.148 & 0.000 \\
\hline S. leucogaster & 0.000 & 0.000 & 0.000 & 0.000 & 0.232 \\
\hline S. camtschaticus & 0.000 & 0.000 & 0.139 & 0.000 & 0.138 \\
\hline S. vagrans & 0.000 & 0.166 & 0.000 & 0.117 & 0.279 \\
\hline$\dagger S$ paearaneus & 0.271 & 0.525 & 0.997 & 0.000 & 0.636 \\
\hline$\dagger$ S. runtonensis & 0.000 & 0.292 & 0.933 & 0.000 & 0.135 \\
\hline$\dagger S$. thaleri & 0.000 & 0.830 & 0.808 & 0.000 & 0.142 \\
\hline$\dagger S$. doronichevi & 0.468 & 0.366 & 0.533 & 0.000 & 0.106 \\
\hline
\end{tabular}

The fossil species also show a very low level of variability of this character. OnlyS. doronichevifrom theCaucasus differs having a relatively high value of $H(0.468)$.

\section{Mandibular/postmansibular foramina com-} plex (MPF-complex)

General variation and patterning. In the Soricinae species the mandibular and postmandibular foramina are situated on the lingual side of the ascending ramus of the mandible. As in other mammals the mandibular foramen opens into a canal running in the direction of the horizontal ramus of the mandible (morphotype 1 ), or it opens into a canal running in the direction of the internal temporal fossa (morphotype 3 ). The postmandibular foramen opens into vertical canal running to the internal temporal fossa (morphotypes 2 and 3) (Fig. 2). In the Soricidae the internal temporal fossa is deeply pocketed which may be defined as the synapomorphy. Therefore the presence of the postmandibular foramen can also be considered as the unique synapomorphy of the Sori- cidae. Both foramina form quite a complex structure named by the authors of the present paper the mandibular/postmandibular foramina complex (MPF-complex).

In the Soricinae there are several patterns of MPFcomplex and all of them were found in species of the genus Sorex.

Three main morphotypes of the MPF-complex were defined (Fig. 2).

Morphotype 1 . There is only one (mandibular) foramen visible (Fig. 2A), the postmandibular foramen is absent.

Morphotype 2. There are two, mandibular and postmandibular, foramina visible, approximately equal in size (Fig. 2B).

Morphotype 3. There is only one postmandibular foramen visible, the mandibular foramen is also present, but not visible from the lingual side (Fig. 2C).

Apart from three morphotypes mentioned above, one can observe one or more very small foramina situated near the mandibular and postmandibular ones running into the internal temporal fossa. All these cases were not taken into consideration. 

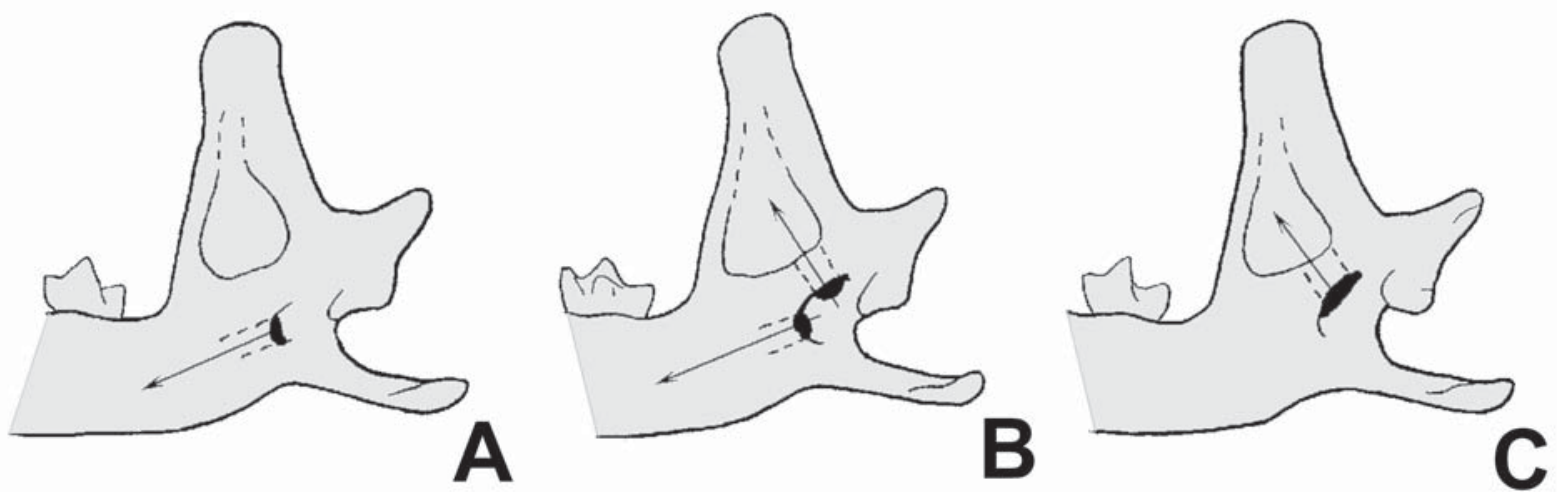

Figure 2. Structure of MPF-complex in Sorex species (explanation in the text). A - morphotype 1; B - morphotype 2; C - morphotype 3.

Variation in the Sorex species. The frequency of the morphotypes of the MPF-complex and the value of the entropy are represented in Tabs. 1 and 3, and in Fig. 5B. They show that this character is more variable than the previous one. Among the recent shrews only about 1/ 3 (6) of all the examined species have $H$ equal to 0 . Five species are characterized by a moderate value of entropy that is by more or less its median level. Only $S$. trowbridgii differs having a high variation of the MPFcomplex $(H=0.939)$. It should be noted that it is a single species in which the morphotype 3 appears more frequently $(41.1 \%)$. In other species is more frequent morphotype 2, whereas the morphotype 1 is observed very seldom. As a rule, it may be found in very old animals. The single exception of this rule represents $S$. mirabilis Ognev, 1937. In this species the ratio of the first two morphotypes equals $1: 2$.

By contrast, among the species of the subgenus Otisorex the first morphotype of the MPF-complex prevails $(98.3-100 \%)$. The frequencies of other morphotypes are lower than the mean of statistical error.

Three from four fossil species have frequencies of the morphotypes typical of the subgenus Sorex. Only $S$. thaleri has 1:1 ratio of two first morphotypes that is unique in the genus Sorex (Tab. 1).

\section{Shape of the interarticular area of the condy-} loid process

General variation and patterning. The morphology of the Soricidae condyloid process principally differs from that of other mammals. It is characterized by two (upper and lower) facets and interarticular area between them. The last structure significantly varies in the Soricidae and represents one of the main characters in their taxonomy (Repenning, 1967). In the Sorex species the interarticular area is relatively wide. It varies in its size and shape. Two morphotypes concerning the shape of the interarticular area can be recognized (Fig. 3).

Morphotype 1. The interarticular area is narrow in its lower part. Its lingual edge meets approximately the middle of the upper edge of the lower facet and it is straight (Fig. 3A).

Morphotype 2. Interarticular area is wide in its lower part. Its lingual edge meets approximately the end of the upper edge of the lower facet and is more or less concave.

This division corresponds roughly to the presently accepted in paleontology terms: "rectangular" and "trapezoid" (Rzebik-Kowalska, 1991).

Sometimes it is difficult to include particular specimens to one morphotype or another. For such cases the third "intermediate" morphotype was introduced (Tab. 1).

Variation in the Sorex species. The frequencies of morphotypes and the values of entropy of the shape of the interarticular area are shown in Tabs. 1 and 3, and in Fig. 5C. As may be seen, the variability of this character is considerably higher than in the two previous cases. Almost always half of the recent and all fossil species have $H$ exceeding the median value. As this takes place, in many species the proportion of "intermediate" morphotype is very high, between 46.7-62.0\%. Only four species, S. isodon Turov, 1924, S. mirabilis, S. leucogaster, and $S$. vagrans are characterized by the absence of the shape variability of the interarticular area.
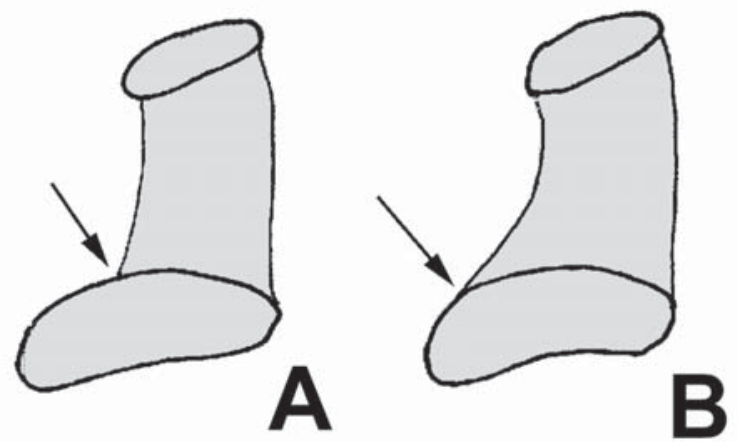

Fig. 3. Structure of interarticular region of condyloid process in Sorex species.

A - morphotype 1; B - morphotype 2 . 
Pigmentation pattern of the first lower incisor (i1)

General variation and patterning. In comparison with other mammals, the first lower incisor il in shrews is large and elongated in the antero-posterior direction. As a rule, in Sorex species its cutting edge has one or more cusps. On the buccal side of $i 1$ the pigment spreads mainly in the anterior and upper parts of the crown. On the lingual side it covers only apex and a thin zone along the lower edge of the crown (Fig. 4). Carraway (1995) was the first who pointed to the difference in pigmentation pattern of the lingual side on il in some American species of shrews. In the present paper a little modification was made and two morphotypes were recognized.

Morphotype 1. A rather wide and flat crest forms the ventrolingual edge of the crown of il. Strips of pigment on the ventrolingual and buccal sides of this tooth are approximately equal and do not exceed half of the crown length (Fig. 4A).

Morphotype 2. A rather thin and rounded crest forms the ventrolingual edge of the crown of i1. Strip of pigment on the ventrolingual side is much longer than the strip on the buccal side of the tooth and exceeds half of the crown length (Fig. 4B).

Variation in the Sorex species. The frequencies of morphotypes and the value of entropy of il pigmentation pattern are presented in Tabs. 2 and 4, and in Fig. 6A. They show that this character has a very low value of variability and may be treated as the most stable one. None of the species have the mean of $H$ reaching $1 / 2$ of the median entropy level. il recent and all fossil species are absolutely invariable. It should also be noted that in all
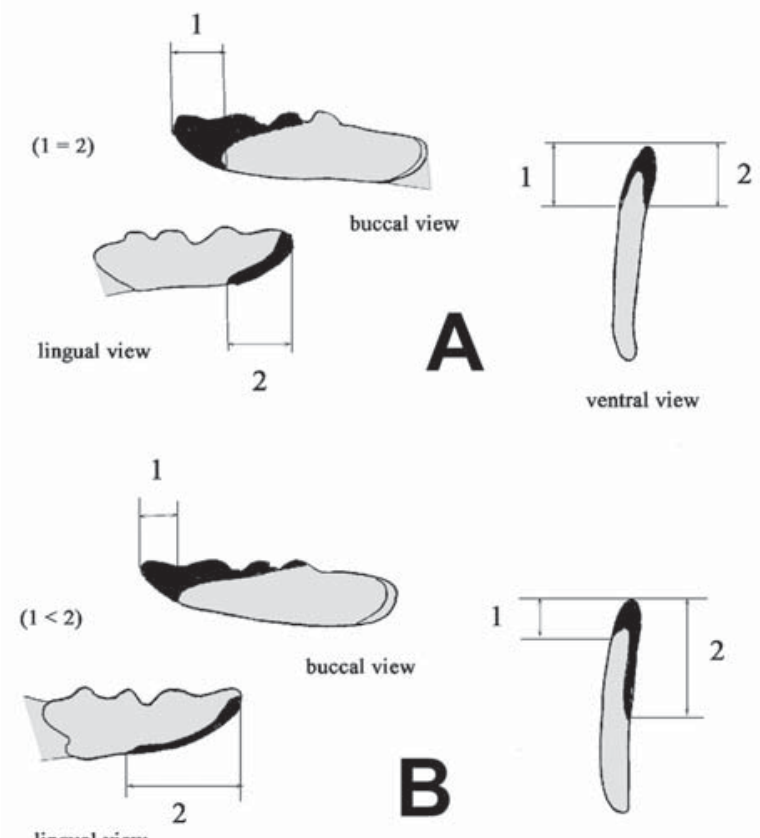

lingual view

ventral view

Figure 4. Types of pigmentation of the first lower incisor in Sorex species (explanation in the text).

A - morphotype 1; B - morphotype 2; C - morphotype 3. shrews of the subgenus Sorex morphotype 1 prevails, whereas the examined species of the subgenus Otisorex are characterized by morphotype 2 . The single exception of this rule is $S$. trowbridgii. In spite of its belonging to the subgenus Sorex, it has the pattern of il pigmentation observed in the Otisorex species (Tab. 2).

\section{Color of the tooth pigment}

General variation and patterning. The red color of tooth pigment of the red-toothed shrews is due to the presence of iron in the enamel tooth (Dötsch \& Koenigswald, 1978; Vogel, 1984). The intensity of the red color widely differs in various genera of the Soricinae. It may be very light yellow to very light orange (Nectogale), or darkish red (Sorex, Blarina). Among Sorcini light orange color of teeth is characteristic mainly for one fossil genus/subgenus Drepanosorex, but sometimes it can be also present in some specimens of various species of the
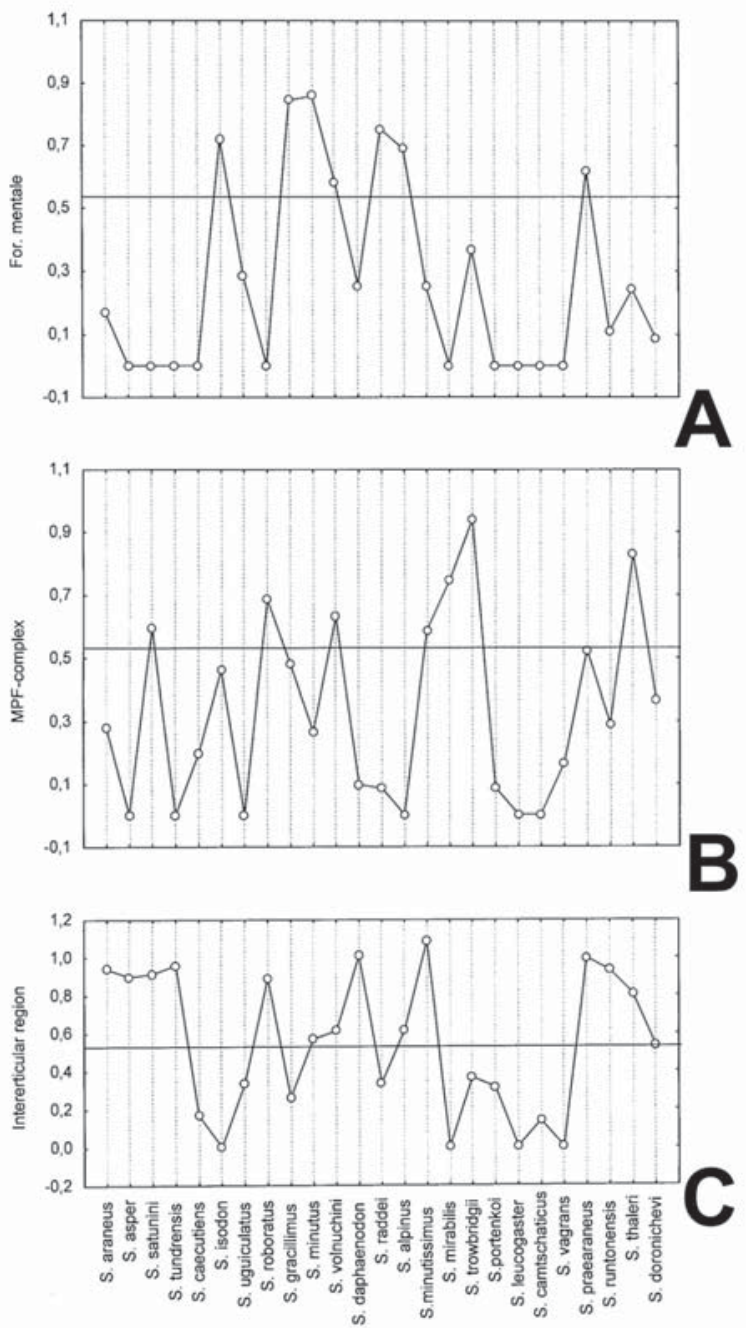

Figure 5. Values of Shannon entropy for three structural characters in Sorex species.

A - position of mental foramen; B - structure of MPF-complex; $\mathrm{C}$ - structure of interarticular region of condyloid process (horizontal line in the bar shows the median level of entropy). 

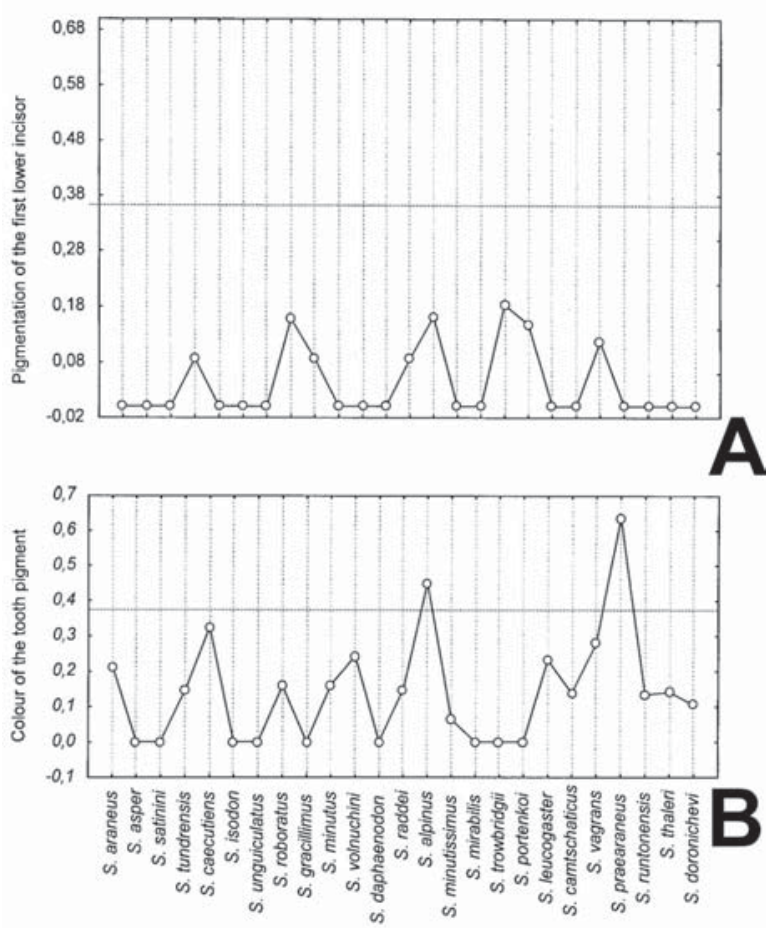

Figure 6. Values of Shannon entropy for two characters of teeth pigmentation in Sorex species.

A - pigmentation of the first lower incisor; B - color of the teeth pigment (horizontal line in the bar shows the median level of entropy).

red-toothed shrews. Two main morphotypes of the tooth pigmentation are recognized:

Morphotype 1 . The color of the tooth pigment is light orange.

Morphotype 2. The color of the tooth pigment is light or darkish red.

Variation in the Sorex species. The frequencies of morphotypes and the value of entropy of tooth pigmentation in Sorex species are represented in Tab. 2 and 4, and in Fig. 6B. They show that the most of shrews are characterized by a relatively low level of variation of this character. Only recent $S$. alpinus and fossil $S$. praearaneus have $H$ that exceeds the median entropy level. The share of morphotype 1 in these species equals to $16.7 \%$ and $33.3 \%$ of the examined specimens, respectively. In other species the share of morphotype 1 does not exceed, as a rule, $5.0 \%$, and very seldom (in $S$. isodon, $S$. volnuchini Ognev, 1922, S. leucogaster, S. vagrans) reaches $6.2-10.0 \%$. Morphotype 2 is more characteristic for the majority of fossil and recent species of both subgenera.

\section{Discussion}

The results presented above show that none of the characters examined may be treated as absolutely certain and informative. Each of them has a specific level of variation, which should be taken into account in preparing any taxonomic hypothesis. In this regard it should be pointed that the diagnosis of species, especially paleon- tological ones, that base on one character only cannot be reliable and effective. On the other hand, using a number of various characters that do not correlate in their variability may be more fruitful.

The majority of characters examined will also be available for the characteristic of various taxonomic groups. For example, as can be observed in the material presented above, the anterior position of the mental foramen is very characteristic for $S$. alpinus. However, it does not mean that other type of variability of this character could be found in this species. In the similar manner the "alpinus" type of the position of the mental foramen is sometimes present in other species (e.g. $S$. raddei, S. minutus, S. gracillimus).

The presence of the postmandibular foramen (morphotypes 2 and 3) is characteristic for the subgenus Sorex, while the absence of this foramen for the subgenus Otisorex. This estimation has a certain "normal" level of probability. As a rule, the variation of MPFcomplex does not exceed $5 \%$ and very seldom $8-12 \%$. So, for species that show the variation that exceeds these values mentioned above one can put a question concerning their taxonomic position. Among the Sorex species a great variation of the MPF-complex structure is noted in $S$. trowbridgii and S. mirabilis. It is quite possible that the last species are a taxonomically distant form from the most typical species of both subgenera.

Among characters studied in the present paper, the morphology of interarticular area seems to be the most variable. Besides its great level of variability it is difficult to find any regularity in the distribution of various morphotypes in different taxonomic groups of the genus. On the contrary, as it is evident from the data presented above, the pattern of pigmentation of the first lower incisor is the most stable, and may be used for diagnostics of subgenera Sorex and Otisorex (except $S$. trowbridgii).

Besides, it should be noted that the level of variation of tooth pigmentation is considerably lower than in any other morphological character. The red type of tooth pigment is characteristic for the genus Sorex and may be used as a good taxonomic feature together with other diagnostic ones.

ACKNOWLEDGEMENTS. We are very grateful to all colleagues from the Carnegie Museum of Natural History in Pittsburgh (USA), especially Dr. Joseph P. Merrit and Dr. Suzanne McJaren, and colleagues from the Zoological Museum of Moscow University for the help in making their collections available to us. We are also thankful to Dr A. Averianov for the editing the manuscript.

\section{References}

Brünner H., Lugon-Moulin N., Balloux F., Fumagalli L. \& Hausser J. 2002. A taxonomic re-evaluation of the Valais chromosome race of the common shrew Sorex araneus (Insectivora: Soricidae) // Acta Theriologica. Vol.47. No.3. P.245-275.

Carraway L.N. 1995. A key to recent Soricidae of the Western United States and Canada based primarily on dentaries // Natural History Museum, The University of Kansas. 
Occasional Papers. No.175. P.1-49.

Dannelid F. 1989. Medial tines on the upper incisors and other dental features used as identification characters in European shrews of the genus Sorex (Mammalia, Soricidae) // Zeitschrift für Säugetierkunde. Bd.54. Hf.2. P.205-214.

Dolgov V.A. 1985. [The long-tailed shrews of the Old World] Moskva: Izdatel'stvo Moskovskogo Universiteta. 221 p. [in Russian].

Dötsch C. \& Koenigswald W. von. 1978. Zur Rotfärbungvon Soricidenzähnen // Zeitschrift für Säugetierkunde. Bd.43. Hf.1. S.65-78.

Junge J.A. \& Hoffmann R.S. 1981. An annotated key to the long-tailed shrews (genus Sorex) of the United States and Canada, with notes on Middle American Sorex // Natural History Museum, The University of Kansas. Occasional Papers. No.94. P.1-48.

Lapini L. \& Testone R. 1998. A new Sorex from north-eastern Italy (Mammalia, Insectivora: Soricidae) // Gortania. Atti del Museo Friulano de Storia Naturale. Vol.20. P.231-250.

Qiu Z. \& Storch G. 2000. The early Pliocene micromammalian fauna of Bilike, Inner Mongolia, China (Mammalia: Lipotyphla, Chiroptera, Rodentia, Lagomorpha)// Senckenbergiana Lethaea. Bd.80. Hf.1. P.173-229.

Repenning C A. 1967. Subfamilies and genera of the Soricidae // United States Geological Survey Professional Paper. No.565. P.1-74.

Reumer J.W.F. 1984. Ruscinian and early Pleistocene Soricidae (Insectivora, Mammalia) from Tegelen (The Netherlands) and Hungary // Scripta Geologica. No.73. P.1-173.

Reumer J.W.F. 1985. The generic status and species of Drepanosorex reconsidered (Mammalia, Soricidae) // Revue de Palébiologie. T.4. No.1. P.53-58.

Rzebik-Kowalska B. 1991. Pliocene and Pleistocene Insectivora (Mammalia) of Poland. VIII. Soricidae: Sorex
Linnaeus, 1758, Neomys Kaup, 1829, Macroneomys Fejfar, 1966, Paenelimnoecus Baudelot, 1972 and Soricidae indeterminate // Acta Zoologica Cracoviensia. Vol.34. No.2. P.323-424.

Rzebik-Kowalska B. 1994. Pliocene and Quaternary Insectivora (Mammalia) of Poland // Acta Zoologica Cracoviensia. Vol. 37. No.1 P.77-136.

Rzebik-Kowalska B. 2000. Insectivora (Mammalia) from the Early and early Middle Pleistocene of Betfia in Romania. I. Soricidae Fisher von Waldheim, 1817 // Acta Zoologica Cracoviensia. Vol.43. No.1. P.1-53.

Sergeev V.E. \& Kharitonova N.A. 1987. [The morphological analysis of the mandible of the shrews (Soricidae) of the fauna of West Siberia] // Yudin B.S. (ed.). [Fauna, Taxonomy and Ecology of Mammals and Birds]. Novosibirsk: Nauka. P.61-66 [in Russian].

Storch G. 1995. Th Neogene Mammalian faunas of Erteme and Harr Obo in Inner Mongolia (Nei Mongol), China. 11. Soricidae (Insectivora) // Senckenbergiana Lethaea. Vol.75. P.221-251.

Vogel P. 1984. Verteilung des roten Zahnschmelzes im Gebiss der Soricidae (Mammalia, Insectivora) // Revue Suisse de Zoologie. T.91. Fasc.3. P.699-708.

Wolsan, M. \& Hutterer R. 1998. A list of the living species of shrews // Wójcik J.M. \& Wolsan M. (eds.). Evolution of Shrews. Bialowieza: Mammal Research Institute, Polish Academy of Sciences. P.425-458.

Yudin B.S. 1989. [Insectivore Mammals of Siberia]. Novosibirsk: Nauka. 360 p. [in Russian].

Zaitsev M.V. \& Baryshnikov G.F. 2002. Pleistocene Soricidae (Lipotyphla, Insectivora, Mammalia) from Treugolnaya Cave, Northern Caucasus, Russia // Acta Zoologica Cracoviensia. Vol.45. No.2. P.283-305.

Zyll de Jong C.G. 1978. Handbook of Canadian Mammals. Ottawa: National Museum of Natural Sciences. 210 p.

\section{Appendix. Specimens examined}

\begin{tabular}{|c|c|c|c|c|c|c|c|}
\hline Species & $\begin{array}{c}\text { Number of } \\
\text { specimens } *\end{array}$ & $\begin{array}{c}\text { Number of } \\
\text { localities }\end{array}$ & Museums & Species & $\begin{array}{l}\text { Number of } \\
\text { specimens } *\end{array}$ & $\begin{array}{c}\text { Number of } \\
\text { localities }\end{array}$ & Museums \\
\hline S. araneus & 50 & 4 & 1 & S. alpinus & 24 & 5 & 1,2 \\
\hline S. asper & 11 & 3 & 1,2 & S. minutissimus & 64 & 17 & 1,2 \\
\hline S. satunini & 37 & 8 & 1,2 & S. mirabilis & 24 & 2 & 1,2 \\
\hline S. tundrensis & 50 & 2 & 1 & S. trowbridgii & 146 & $3(?)$ & $1,2,3$ \\
\hline S. caecutiens & 50 & 5 & 1 & S. camtschaticus & 32 & 4 & 1 \\
\hline S. isodon & 50 & 5 & 1 & S. portenkoi & 30 & 7 & 1 \\
\hline S. unguiculatus & 50 & 3 & 1 & S. leucogaster & 16 & 1 & 1 \\
\hline S. roboratus & 50 & 9 & 1 & S. vagrans & 52 & 7 & 2 \\
\hline S. gracillimus & 70 & 6 & 1 & $\dagger S$. praearaneus & 23 & 5 & 4 \\
\hline S. minutus & 53 & 6 & 1 & $\dagger$ S. runtonensis & 111 & 4 & 4 \\
\hline S. volnuchini & 37 & 5 & 1,2 & $\dagger S$. thaleri & 35 & 1 & 4 \\
\hline S. daphaenodon & 99 & 12 & 1 & $\dagger S$. doronichevi & 75 & 1 & 1 \\
\hline$S$. raddei & 58 & 14 & 1,2 & & & & \\
\hline
\end{tabular}

* The number of skulls for recent species and number of mandibles for fossil ( $\dagger$ ) species.

1 - Zoological Institute of the Russian Academy of Sciences, Saint Petersburg.

2 - Zoological Museum of the Moscow University, Moscow.

3 - Carnegie Museum of Natural History, Pittsburgh.

4 - Institute of Systematics and Evolution of Animals of the Polish Academy of Sciences, Krakow. 